\title{
STRUKTUR KRISTAL DAN KOMPOSISI KIMIA SEMIKONDUKTOR CD(SE0,6TE0,4) HASIL PREPARASI DENGAN METODE BRIDGMAN
}

\author{
Rizalul Fiqry ${ }^{1, a)}$, Ariswan ${ }^{2}$, Heru Kuswanto ${ }^{3}$ \\ ${ }^{I}$ Mahasiswa Pendidikan Fisika Pascasarjana Universitas Ahmad Dahlan (UAD) \\ ${ }^{2}$ Dosen Universitas Negeri Yogyakarta (UNY)

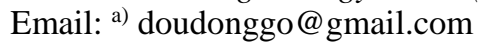

\begin{abstract}
Abstrak
Telah dilakukan penumbuhan kristal bahan semikonduktor $\mathrm{Cd}(\mathrm{Se} 0,6 \mathrm{Te} 0,4)$ dengan metode Bridgman. Penelitian ini bertujuan mengetahui komposisi kimia, parameter kisi, struktur kristal dan morfologi kristal bahan semikonduktor $\mathrm{Cd}(\mathrm{Se} 0,6 \mathrm{Te} 0,4)$. Pemanasan tahap pertama dari suhu $27^{\circ} \mathrm{C}>200^{\circ} \mathrm{C}>250^{\circ} \mathrm{C}>300^{\circ} \mathrm{C}$ masing-masing $1 \mathrm{jam}, 400^{\circ} \mathrm{C}(2 \mathrm{jam})$, lalu furnace dimatikan hingga $27^{\circ} \mathrm{C}$ (2,25 jam). Tahap kedua dilakukan 16 jam kemudian, dimulai dari suhu $27^{\circ} \mathrm{C}>200^{\circ} \mathrm{C}>300^{\circ} \mathrm{C}$ masingmasing 30 menit, ke $400^{\circ} \mathrm{C}$ dan $500^{\circ} \mathrm{C}$ masing-masing $1 \mathrm{jam}, 600^{\circ} \mathrm{C}(2 \mathrm{jam})$, furnace dimatikan hingga $27^{\circ} \mathrm{C}$. Penelitian menggunakan 4 sampel, melalui kerakterisasi XRD dan penghitungan parameter kisi menggunakan metode analitik dipilih sampel $4(\mathrm{Cd}=0,362$ gram, $\mathrm{Se}=0,858$ gram dan $\mathrm{Te}=0,390$ gram $)$ untuk diuji karakterisasi menggunakan EDAX dan SEM. Hasil karakterisasi XRD sampel 4 menunjukkan telah terbentuk fase $\mathrm{Cd}(\mathrm{Se} 0,6 \mathrm{Te} 0,4)$ terkristalisasi dalam struktur heksagonal, dengan parameter kisi $\mathrm{a}=\mathrm{b}=4,2941 \AA \AA$ dan $\mathrm{c}=6,9975 \AA \AA$. Setelah dilakukan analisis SEM dan EDAX menunjukkan massif yang dihasilkan cukup homogen dengan perbandingan mol Cd:Se:Te=1:0.70:0.40.
\end{abstract}

Kata-kata kunci: Metode Bridgman, Struktur Kristal, Komposisi Kimia, Morfologi Permukaan $\mathrm{Cd}(\mathrm{Se} 0,6 \mathrm{Te} 0,4)$

\begin{abstract}
Has made crystal growing a semiconductor material $\mathrm{Cd}(\mathrm{Se} 0,6 \mathrm{Te} 0,4)$ with Bridgman method. This study aims to determine the chemical composition, lattice parameters, crystal structure and morphology of crystalline semiconductor material $\mathrm{Cd}(\mathrm{Se} 0,6 \mathrm{Te} 0,4)$. The first stage of the heating temperature of $27^{\circ}$ C> $200^{\circ} \mathrm{C}>250^{\circ} \mathrm{C}>300^{\circ} \mathrm{C}$ respectively 1 hour, $400^{\circ} \mathrm{C}$ ( 2 hours), then the furnace was turned off to $27^{\circ} \mathrm{C}$ ( 2.25 hours). The second phase dilakukan 16 hours later, starting from a temperature of $27^{\circ} \mathrm{C}>$ $200{ }^{\circ} \mathrm{C}>300^{\circ} \mathrm{C}$ each for 30 minutes, to $400^{\circ} \mathrm{C}$ and $500^{\circ} \mathrm{C}$ respectively 1 hour, $600^{\circ} \mathrm{C}$ ( 2 hours), the furnace was turned off up to $27^{\circ}$ C.The study used four samples, through kerakterisasi XRD and calculation of lattice parameters using the analytical method selected sample $4(\mathrm{Cd}=0.362 \mathrm{gram}, \mathrm{Se}$ and $\mathrm{Te}=0.858$ grams $=0.390$ gram) to be tested using EDAX and SEM characterization. XRD characterization results have formed the sample 4 shows the phase $\mathrm{Cd}(\mathrm{Se} 0,6 \mathrm{Te} 0,4)$ crystallizes in a hexagonal structure with lattice parameters $\mathrm{a}=\mathrm{b}=\mathrm{c}=4,2941 \AA$ and $6,9975 \AA$. After the analysis of SEM and EDAX showed massif produced quite homogenous with the mole ratio of $\mathrm{Cd}$ : $\mathrm{Se}: \mathrm{Te}=1:$ 0.70: $12: 40$.
\end{abstract}

Keywords: Bridgman method, crystal structure, chemical composition, surface morphology of $\mathrm{Cd}(\mathrm{Se} 0,6 \mathrm{Te} 0,4)$ 


\section{PENDAHULUAN}

Penggunaan energi dewasa ini sangat tinggi, khususnya energi listrik. Penelitian dan riset terus dilakukan demi pemenuhan akan kebutuhan energi listrik. Salah satu riset yang terus dikembangkan dalam pemenuhan kebutuhan energi listrik adalah pembuatan piranti sel surya. Bahan yang digunakan adalah bahan semikonduktor dalam bentuk sambungan $\mathrm{p}$-n tertentu sehingga menghasilkan efek perubahan dari energi matahari langsung menjadi energi listrik.

Penumbuhan kristal di laboratorium dilakukan dengan dua metode. Metode Czockralski (metode penarikan) yaitu menarik benih kristal dan kristal cair yang saling menempel ke atas pada alat penarik, dan metode Bridgman yaitu penumbuhan dengan melelehkan bahan-bahan yang telah dimurnikan dalam tabung pyrex yang telah divakumkan.

Pada penelitian ini, penumbuhan kristal $\mathrm{Cd}(\mathrm{SeO}, 6 \mathrm{Te} 0,4)$ dilakukan dengan metode Bridgman. Metode ini dipilih sesuai dengan penentuan laboratorium yang ada, yaitu dengan melelehkan bahan di dalam tabung pyrex yang telah divakumkan. Keunggulan metode ini adalah dapat menghasilkan massif/ingot yang lebih homogen, penurunan temperatur pada perubahan bahan dari keadaan awal (cair) dapat dikontrol secara teliti, dapat mengatur kecepatan pembekuan, dan dapat mengurangi kemungkinan ledakan unsur bahan pada suhu kristal dengan mengatur kenaikan suhunya.

Metode ini dapat dilakukan dengan dua cara, yaitu metode Bridgman horizontal dan vertikal. Perbedaan kedua metode ini hanya terletak pada posisi ampoule di dalam furnace saat pemanasan.

Untuk mengetahui hasil preparasi dilakukan karakterisasi dengan menggunakan X-Ray Diffraction (XRD) berikut dengan penentuan struktur kristal, Scanning Electron Microscopy (SEM) digunakan untuk mengetahui morfologi permukaan (ukuran butir kristal) dan Energy Dispersive Analysis X-Ray (EDAX) digunakan untuk mengetahui komposisi kimia secara kuantitatif.

Penumbuhan kristal dengan metode Bridgman sendiri beberapa kali telah dilakukan di FMIPA UNY. Salah satunya Mukti Dwi Nurjannah (2010) dengan Bahan Semikonduktor $C d(\operatorname{Se} 0,5 T e 0,5)$ dengan kesimpulan, merfologi bahan terlihat homogen[1].

\section{Batasan masalah}

Batasan masalah dalam penelitian ini adalah penumbuhan kristal $\mathrm{Cd}(\mathrm{Se} 0,6 \mathrm{Te} 0,4)$ menggunakan metode Bridgman dengan melakukan variasi waktu pemanasan pada temperatur tertentu sedangkan karakterisasi kristal yang terbentuk dengan menggunakan XRD, SEM dan EDAX.

\section{Rumusan Masalah}

Rumusan masalah dalam penelitian ini adalah:

1. Bagaimana struktur kristal $\mathrm{Cd}(\mathrm{Se} 0,6 \mathrm{Te} 0,4)$ yang terbentuk?

2. Bagaimana parameter kisi kristal $\mathrm{Cd}(\mathrm{Se} 0,6 \mathrm{Te} 0,4)$ yang terbentuk?

3. Bagaimana komposisi kimia dari unsur kristal $\mathrm{Cd}(\mathrm{Se} 0,6 \mathrm{Te} 0,4)$ yang terbentuk?

4. Bagaimana morfologi permukaan dari unsur kristal $\mathrm{Cd}(\mathrm{Se} 0,6 \mathrm{Te} 0,4)$ yang terbentuk?

\section{Tujuan Penelitian}

Tujuan dari penelitian ini adalah:

1. Mengetahui struktur kristal $\mathrm{Cd}(\mathrm{Se} 0,6 \mathrm{Te} 0,4)$ yang terbentuk.

2. Mengetahui parameter kisi kristal $\mathrm{Cd}(\mathrm{Se} 0,6 \mathrm{Te} 0,4)$ yang terbentuk.

3. Mengetahui komposisi kimia dari unsur kristal $\mathrm{Cd}(\mathrm{SeO}, 6 \mathrm{Te} 0,4)$ yang terbentuk.

4. Mengetahui morfologi permukaan dari unsur kristal $\mathrm{Cd}(\mathrm{SeO}, 6 \mathrm{TeO}, 4)$ yang terbentuk.

\section{KAJIAN PUSTAKA}

\section{Bahan Zat Padat}

Bahan yang tersusun dari deretan atom-atom yang teratur letaknya dan periodik disebut bahan kristal. Kristal memiliki susunan berulang dan jarak yang teratur dalam tiga dimensi. Pada hubungan 
lokal yang teratur, suatu kristal harus memiliki rentang yang panjang sebagai karakteristik dari bentuk kristal tersebut. Selain kristal ada juga yang disebut amorf (amorphous). Amorf merupakan definisi struktual dari suatu material, dimana atom-atomnya tersusun secara tidak teratur sehingga panjang dan sudut ikatan antar atom juga tidak teratur, kasus inilah yang diketahui sebagai bentuk penyimpangan struktural[2].

Kristal adalah zat padat yang mempunyai susunan atom-atom atau susunan molekul yang teratur. Berdasarkan keteraturan panjang jarak susunan atom-atom atau molekul-molekul zat padat, maka kristal dibagi menjadi dua, yaitu; Monokristal (kristal tunggal), yaitu kristal yang memiliki keteraturan panjang jarak susunan atom-atom dan memiliki periodisitas yang tidak berhingga ke segala arah dan Polikristal adalah kristal yang memiliki keteraturan, dengan panjang (jarak) susunan atom-atom hanya terbatas pada daerah-daerah tertentu di dalam kristal zat padat. Daerah dengan keteraturan atom-atom ini disebut butiran (grain). Dalam sistem tiga dimensi kristal dikelompokkan menjadi tujuh sistem kristal, yaitu kubik, monoklinik, triklinik, tetragonal, orthorombik, trigonal, dan heksagonal[3].

\section{Kristal Cd(Se0,6Te0,4) Sebagai Bahan Sel Surya}

Semikonduktor adalah bahan dengan konduktivitas listrik karena aliran elektron (sebagai lawan konduktivitas ionik ) yang besarnya antara yang dari konduktor dan isolator. Berdasarkan struktur pita energi bahan dapat digolongkan menjadi tiga jenis yaitu isolator, konduktor dan semikonduktor. Isolator adalah penghantar listrik yang buruk karena memiliki daerah terlarang sangat lebar yaitu sekitar $\approx 6 \mathrm{eV}$, keberadaan pita terlarang ini memisahkan daerah pita valensi yang penuh dan yang kosong sehingga mengakibatkan terhambatnya serapan energi bagi elektron.

Semikonduktor terbagi menjadi dua, Semikonduktor intrinsik yaitu semikonduktor yang masih murni dan semikonduktor ekstrinsik adalah semikonduktor intrinsik yang dikotori oleh ketidakmurnian, sehingga sifat kelistrikannya dikendalikan oleh sifat-sifat dan jumlah ketidakmurnian pada bahan itu sehingga terbagi menjadi Semikonduktor tipe-ndan tipe-p[4].

Pada suhu $0 \mathrm{~K}$ semikonduktor akan bersifat isolator karena pita valensi terisi penuh dan pita konduksi kosong. Jadi hantaran listrik pada semikonduktor sangat bergantung pada suhu dibanding hantaran listrik pada konduktor dan isolator[5].

Bahan yang banyak dipakai sebagai bahan semikonduktor adalah silikon dan germanium dengan Eg berturut-turut $1,21 \mathrm{eV}$ dan $0,785 \mathrm{eV}$ pada suhu $0 \mathrm{~K}$, jika temperatur dinaikkan sebagian elektron valensi mempunyai panas termal yang lebih besar dari $\mathrm{Rg}$, oleh kerena itu elektron berpindah ke pita konduksi sebagian elektron hampir bebas dan meninggalkan hole di pita valensi. Bahan tersebut bersifat sebagai konduktor pembawa muatan elektron dan hole. Bahan tersebut dinamakan semikonduktor intrinsic[6].

Bahan semikonduktor $\mathrm{Cd}(\mathrm{SeO}, 6 \mathrm{Te} 0,4)$ terbentuk dari tiga unsur, yaitu $\mathrm{Cd}$ (golongan II), $\mathrm{Se}$ dan $\mathrm{Te}$ (golongan IV). Bahan semikonduktor $\mathrm{Cd}(\mathrm{Se} 0,6 \mathrm{Te}, 4)$ identik dengan bahan semikonduktor Cadmium Selenida (CdSe) dan Cadmium Tellurium (CdTe). Bahan CdSe dan CdTe merupakan bahan semikonduktor tipe-n.

Lipisan tipis kadmium telah menjadi bahan untuk aplikasi di elektro-optik dan foto perangkat elektrokimia sel surya. Saat ini, salah satu bahan terbaik dimana menyambung celah pita mungkin adalah dari kelompok cadmium chalcogenides, yaitu $\mathrm{Cd}(\mathrm{Se} 0,6 \mathrm{TeO}, 4)$ yang memiliki celah pita sangat dekat dengan penyerapan maksimum dalam spektrum terlihat $\approx 1,45 \mathrm{eV}$. Efisiensi konversi listrik hingga $8 \%$ telah diperoleh menggunakan film tipis polikristalin $\mathrm{Cd}(\mathrm{Se} 0.65 \mathrm{TeO} .35)$ yang telah sebuah celah pita optik yang sama dengan $C d T e$ dan menunjukkan stabilitas sebanding dengan $C d S e$ di sulfida[7].

Penumbuhan Kristal $\mathrm{Cd}(\mathrm{SeO}, 6 \mathrm{Te}$,4) dengan Metode Bridgman.

Hal yang paling penting untuk mendapatkan semikonduktor yang berkualitas dan bermutu adalah dengan mendapatkan kristal yang sempurna, maka dalam penumbuhan kristal dapat dilakukan dengan 2 cara, yaitu metode Czockalski (Penarikan) dan Bridgman (Pelelehan).

Untuk Metode Bridgman, bahan yang dilelehkan harus divakumkan dalam tabung pyrex. Metode Bridgman dapat dibagi menjadi dua, yaitu metode bridgaman vertical dan horizontal. Perbedaan kedua metode ini hanya pada posisi tabung pyrex yang dipanaskan dalam furnace. Keunggulan 
metode Bridgman horizontal dapat menyebabkan tegangan tersebar secara homogen, sehingga dapat mengurangi retakan pada kristal yang terbentuk. Pengaruh temperatur sangat penting karena berdampak pada kristal yang dibentuk[8].

Hasil dari perparasi adalah terbentuknya massif atau ingot, yaitu bahan (biasanya logam), yang dilemparkan ke dalam bentuk yang cocok untuk diproses lebih lanjut. Pada preparasi $\mathrm{Cd}(\mathrm{SeO}, 6 \mathrm{Te} 0,4)$ masing-masing bahan memiliki titik lebur, $\mathrm{Cd}=312,07^{\circ} \mathrm{C}, \mathrm{Se}=221^{\circ} \mathrm{C}, \mathrm{Te}=449,5^{\circ} \mathrm{C}$. Pemilihan suhu tersebut berdasarkan titik lebur bahan serta pertimbangan terhadap keadaan bahan pada suhu kritis.

\section{METODE PENELITIAN/EKSPERIMEN}

\section{Rancangan Penelitian}

Penelitian ini menggunakan metode Bridgman, yaitu dengan memelehkan bahan semikonduktor. Penelitian dilakukan April-Juni 2011 Lab. Material Gedung Lab Fisika FMIPA UNY, sedangkan uji XRD di Laboratorium Kimia Analitik Universitas Gadjah Mada, SEM dan EDAX di Laboratorium Pusat Penelitian dan Pengembangan Geologi (LP3G) ITB Bandung.

Variabel dalam penelitian; (1) bebas; jenis material adalah $\mathrm{Cd}(\mathrm{SeO}, 6 \mathrm{Te} 0,4)$ dan temperatur preparasi bahan yaitu $27^{\circ} \mathrm{C}$ s/d $600^{\circ} \mathrm{C}$, (2) terikat; stuktur kristal $\mathrm{Cd}(\mathrm{Se} 0,6 \mathrm{Te} 0,4)$, parameter kisi kristal $\mathrm{Cd}(\mathrm{Se} 0,6 \mathrm{Te} 0,4)$, dan kristalinitas $\mathrm{Cd}(\mathrm{Se} 0,6 \mathrm{Te} 0,4)$, (3) terkontrol; tekanan dan waktu.

Perangkat preparasi bahan semikonduktor $\mathrm{Cd}(\mathrm{Se} 0,6 \mathrm{Te} 0,4)$ dengan metode Bridgman; pompa vakum, alat pemanas (furnace dengan merk barndstead Thermolyne Seri 47900), Timbangan Analitik (timbangan digital merk Denver Instrument XE-310 dengan ketelitian 0,001 gram), pengelas kaca, dan alat tambahan (hair dryer, penjepit tabung, kunci inggris, tang dan obeng). Sedangkan untuk karakterisasi bahan semikonduktor menggunakan XRD (X-Ray Diffraction), SEM (Scanning Electron Microcopy) dan EDAX (Energi Dirpersive Analysis X-Ray).

\section{Bahan Penelitian}

Bahan-bahan yang digunakan dalan penelitian ini adalah; (1) Cadmium (serbuk), dengan kemurnian 99,99\% (Nomor atom: 48, Warna: Logam Kebiruan, Berat Atom: 112,41 gram/mol, Titik leleh: : 321,07 ${ }^{\circ} \mathrm{C}$, Titik didih: $767{ }^{\circ} \mathrm{C}$, Struktur Kristal: Homogen), (2) Selenium (pellet), dengan kemurnian 99,99\% (Nomor atom : 34, Warna: metalik, Berat atom: 78,96 gram $/ \mathrm{mol}$, Titik leleh: $221^{\circ} \mathrm{C}$, Titik didih: $685{ }^{\circ} \mathrm{C}$, Struktur Kristal: Hexagonal), (3) Tellurium (pellet), dengan kemurnian 99,99\% (Nomor atom: 52, Warna: metalik, Berat atom: 127,6 gram/mol, Titik leleh $449,5^{\circ} \mathrm{C}$, Titik didih: $988{ }^{\circ} \mathrm{C}$, struktur kristal: Kubik), (4) Tabung pyrex dengan ketebalan $2 \mathrm{~mm}$, diameter dalam $12 \mathrm{~mm}$, dan diameter luar $16 \mathrm{~mm}$, (5) Larutan Hf 10\%, air dan alkohol, (6) Plastik tempat sampel.

Teknik pengambilan data dibagi dua, yaitu tahap persiapan preparasi dan proses pelaksanaan preparasi. Jumlah Sampel yang Dijadikan Bahan Preparasi, 4. Kemudian nanti dipilih salah satu sampel yang bagus untuk dilanjutkan ke tahap preparasi yang lain.

Preparasi Penumbuhan Kristal $\mathrm{Cd}(\mathrm{Se} 0,6 \mathrm{TeO}, 4)$ dengan menggunakan metode Bridgman, tahap preparasi bahan; (1) membersihkan tabung pyrex, (2) Menyiapkan bahan dasar yaitu Cadmium (Cd), Selenium (Se) dan Tellenium (Te), (3) penimbangan bahan, dengan persamaan:

Massa $\mathrm{Se}=\mathrm{X}$ gram

Massa Te $=(($ massa Se $) /($ Berat atom Se $) \times$ Berat atom Te x 0,4/0,6)

Massa $\mathrm{Cd}=(($ massa Se $) /($ Berat atom Se $) \times$ Berat atom $\mathrm{Cd} \times 1 / 0,6$

(4) memasukkan bahan dasar yang telah ditimbang ke dalam tabung pyrex, (1) pemvakuman, (5) Pengelasan, (6) Pemanasan Bahan $\left(27^{\circ} \mathrm{C}, 250^{\circ} \mathrm{C}, 300^{\circ} \mathrm{C}, 400^{\circ} \mathrm{C}, 500^{\circ} \mathrm{C}, 600^{\circ} \mathrm{C}\right.$ sesuai dengan alur pemanasan yang dikehendaki dan suhunya disesuaikan dengan titik lebur dari masing-masing bahan).

Langkah-langkah dalam preparasi adalah; (1) memasukkan bahan kapsul yang berisi $\mathrm{Cd}$, Se, dan Te yang telah ditimbang ke dalam furnace, (2) Menghidupkan furnace dengan mengatur saklar pada posisi ON, (3) mengatur temperatur sesuai dengan alur pemanasan yang dikendaki, (4) mematikan furnace dengan mengatur saklar pada posisi OFF, setelah pemanasan selesai. 
Siklus pemanasan untuk ke-4 sampel: sampel 1, 2 dan 3; (1) pemanasan sampel hari pertama dimulai dari suhu $27^{\circ} \mathrm{C}$ ke suhu $200^{\circ} \mathrm{C}$ dan konstan selama 1 jam. Setelah konstan 1 jam, suhu dinaikkan $250^{\circ} \mathrm{C}$ dan konstan 1 jam, kemudian furnace dimatikan atau kembali ke suhu lingkungan selama 45 menit; (2) pemanasan sampel hari ke dua dimulai dari suhu $200^{\circ} \mathrm{C}$ dan kostan selama 30 menit. Setelah konstan 30 menit, suhu dinaikkan ke $300^{\circ} \mathrm{C}$ dan konstan selama 1 jam. Kemudian suhu dinaikkan lagi ke $400^{\circ} \mathrm{C}$ dan konstan selama 2 jam, Kemudian suhu dinaikkan lagi ke $500^{\circ} \mathrm{C}$ dan konstan selama 2 jam. Kemudian furnace dimatikan atau kembali ke suhu lingkungan selama 2,25 jam. Sampel 4; (1) pemanasan sampel hari pertama dimulai dari suhu $27^{\circ} \mathrm{C}$ ke suhu $200^{\circ} \mathrm{C}$ dan konstan selama $1 \mathrm{jam}$. Setelah konstan $1 \mathrm{jam}$, suhu dinaikkan $300^{\circ} \mathrm{C}$ dan konstan $1 \mathrm{jam}$, kemudian suhu dinaikan ke $400^{\circ} \mathrm{C}$ dan konstan selama 2 jam, kemudian furnace dimatikan atau kembali ke suhu lingkungan selama $1,5 \mathrm{jam}$; (2) pemanasan sampel hari ke dua dimulai dari suhu $200^{\circ} \mathrm{C}$ dan kostan selama 30 menit. Setelah konstan 30 menit, suhu dinaikkan ke $300^{\circ} \mathrm{C}$ dan konstan selama 30 menit. Kemudian suhu dinaikkan lagi ke $400^{\circ} \mathrm{C}$ dan konstan selama 1 jam, Kemudian suhu dinaikkan lagi ke $500^{\circ} \mathrm{C}$ dan konstan selama $1 \mathrm{jam}$. Kemudian suhu dinaikkan lagi ke $600^{\circ} \mathrm{C}$ dan konstan selama 2 jam. Kemudian furnace dimatikan atau kembali ke suhu lingkungan 4 jam.

Karakterisasi Bahan Semikonduktor $\mathrm{Cd}(\mathrm{SeO}, 6 \mathrm{Te} 0,4)$ Struktur Kristal $\mathrm{Cd}(\mathrm{SeO}, 6 \mathrm{Te0}, 4)$ dengan XRD, morfologi permukaan dengan SEM dan Komposisi Unsur dengan EDAX.

\section{Teknik Analisis Data}

Data yang diperoleh dari karakterisasi dengan manggunakan XRD adalah hubungan antara intensitas dengan sudut difraksi 20, hasil tersebut kemudian dibandingkan dengan standar JCPDS (Join Committee on Powder Diffraction Standards), sehingga diperoleh bidang-bidang hkl dari sampel, sedangkan untuk mengetahui nilai dari parameter kisi $(a, b$ dan $c)$ yang terbentuk dapat dilakukan dengan metode analitik.

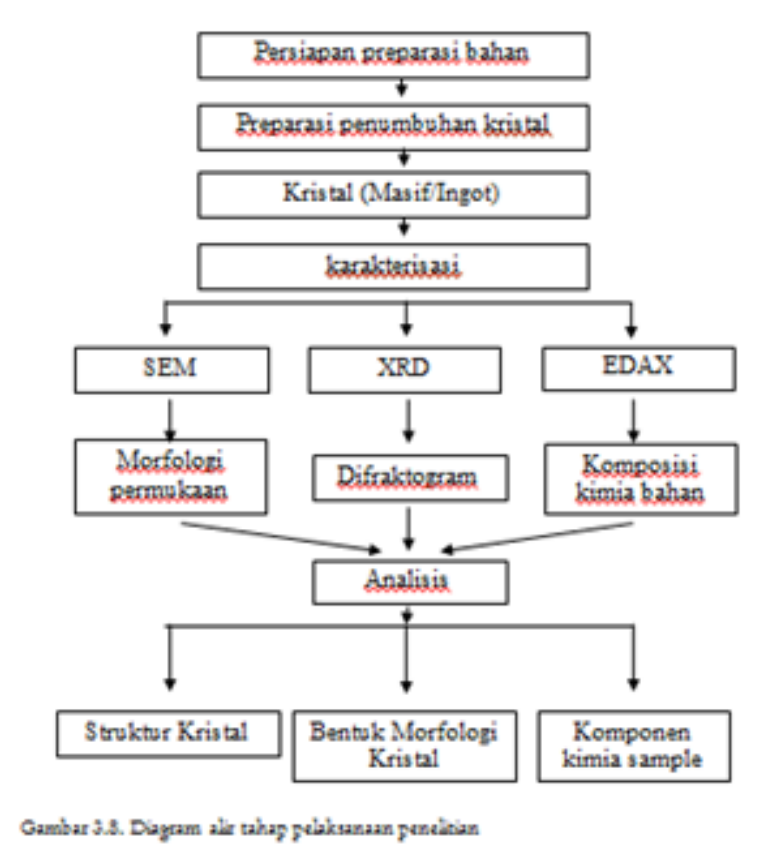

\section{HASIL PENELITIAN DAN PEMBAHASAN}

Hasil Penelitian

Analisis struktur kristal Massif $\mathrm{Cd}(\mathrm{Se} 0,6 \mathrm{Te} 0,4)$ dengan menggunakan XRD

Masif $\mathrm{Cd}(\mathrm{Se} 0,6 \mathrm{Te} 0,4)$ yang sudah dikarakterisasi dengan menggunakan XRD (X-Ray Diffraction) menghasilkan data dalam bentuk difragtogram, yaitu grafik hubungan antara intensitas (I) puncak spektrum kristal dan sudut hamburan (20). Difragtogram menunjukkan puncak-puncak 
spektrum yang muncul pada sampel. Data hasil karakterisasi dengan menggunakan XRD (X-Ray Diffraction).

Dilihat dari hasil dari grafik dengan intensitas yang baik dan hasil perbandingan dari data JCPDS CdSe maka bahan yang paling bagus untuk dilanjutkan uji karakterisasinya adalah bahan 4 .

Analisis struktur kristal Massif $\mathrm{Cd}(\mathrm{SeO}, 6 \mathrm{Te} 0,4)$ dengan menggunakan XRD

Masif $\mathrm{Cd}(\mathrm{Se} 0,6 \mathrm{Te} 0,4)$ yang sudah dikarakterisasi dengan menggunakan XRD (X-Ray Diffraction) menghasilkan data dalam bentuk difragtogram, yaitu grafik hubungan antara intensitas (I) puncak spektrum kristal dan sudut hamburan (20). Difragtogram menunjukkan puncak-puncak spektrum yang muncul pada sampel. Data hasil karakterisasi dengan menggunakan XRD (X-Ray Diffraction). Seperti terlihat pada gambar.

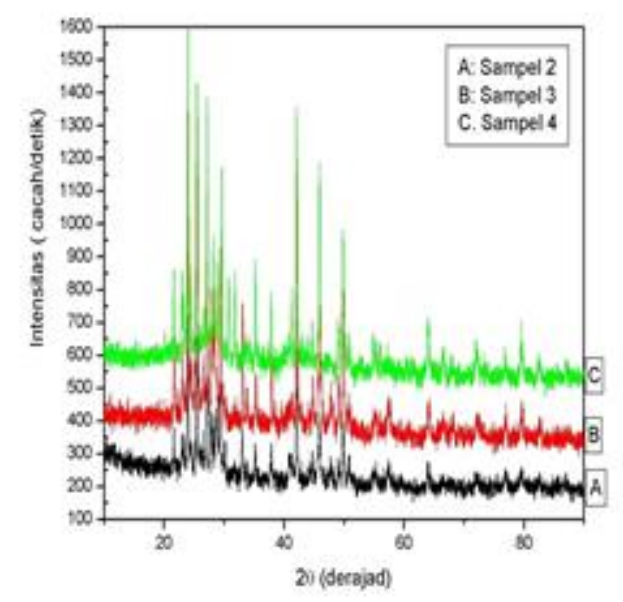

Analisis Morfologi Permukaan Masif Cd(Se0,6Te0,4)dengan Menggunakan SEM.

hasil pemotretan bahan $\mathrm{Cd}(\mathrm{Se} 0,6 \mathrm{Te} 0,4)$ dengan mengunakan SEM (a) perbesaran $1000 \mathrm{x}$ (b) perbesaran $10000 \mathrm{x}$

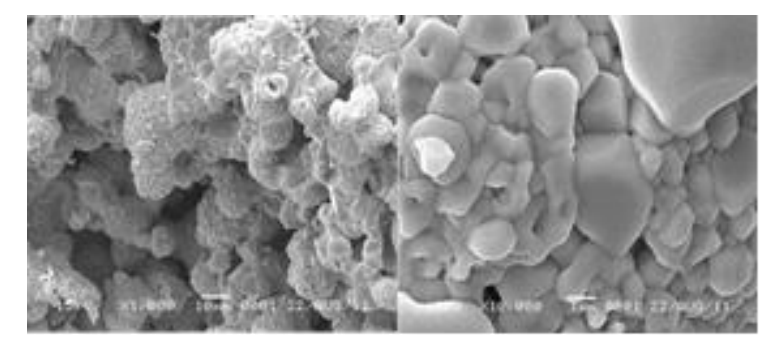

Pembahasan

\section{Komposisi Kimia Masif $\mathrm{Cd}(\mathrm{Se} 0,6 \mathrm{Te} 0,4)$ dengan EDAX}

Hasil perhitungan analitik yang kemudian dibandingkan dengan data JCPDS diketahui bahwa massif $\mathrm{Cd}(\mathrm{Se} 0,6 \mathrm{Te} 0,4)$ yang terbentuk merupakan polikristal dan mempunyai struktur heksagonal, yaitu parameter kisi $(\mathrm{a}=\mathrm{b} \neq \mathrm{c})$ dan sudut $\left(\alpha=\beta=90^{\circ}, \gamma=120^{\circ}\right)$. Sumbu dan sudut antara sumbu dalam kristal 3 dimensi, perpotongan karakteristik dan sudut sumbu suatu kristal dinamakan konstanta geometri. Hal ini sama dengan data JCPDS CdSe dan berdasarkan hasil perhitungan dengan menggunakan metode analitik, hasil perhitugan selengkapnya disajikan pada lampiran 3.

Harga parameter kisi pada massif $\mathrm{Cd}(\mathrm{Se} 0,6 \mathrm{Te} 0,4)$ dari hasil perhitungan dengan metode analitik yaitu: 6,9943 Á.

Bahan $2(\mathrm{Cd}=0,50$ gram, $\mathrm{Se}=0,210$ gram dan $\mathrm{Te}=0,227$ gram $)$ adalah $\mathrm{a}=\mathrm{b}=4,2941 \AA \AA \mathrm{dan} \mathrm{c}=$

- Bahan $3(\mathrm{Cd}=0,271$ gram, $\mathrm{Se}=0,643$ gram dan $\mathrm{Te}=0,259$ gram $)$ adalah $\mathrm{a}=\mathrm{b}=4,2941 \AA \hat{\text { dan }}$

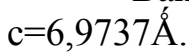
6,9975 Á. 
sedangkan dari data JCPDS CdSe yaitu $\mathrm{a}=\mathrm{b}=4,2990 \AA \AA$ dan $\mathrm{c}=7,0100 \AA$.

Dilihat dari parameter kisi a,b dan c dari masif $C d(S e 0,6 \mathrm{Te} 0,4)$ maka dapat ditarik kesimpulan bahwa preparasi yang dilakukan mendekati berhasil, karena hanya terdapat sedikit selisih dari harga parameter kisinya. Nilai ralat ini mungkin disebabkan kurangnya proses pemanasan serta kurang tingginya tingkat pemvakuman.

Melalui hasil EDAX maka diperoleh perbandingan persentase komposisi kimia unsur Cd:Se:Te adalah 42.02:29.49:16.96 dengan perbandiangan mol Cd:Se:Te adalah 1:0.70:0.40 sedangkan secara teori adalah 1:0.6:0.4. Dari data terdapat unsur lain yang terkandung yaitu $\mathrm{C}$ dengan komposisi kimia $11,52 \%$.

Berdasarkan data terdapat ketidaksesuaian perbadingan mol dan juga terdeteksinya kandungan unsur karbon (C), ini dapat disebabkan karena beberapa vaktor diantaranya ketidaksempurnaan dalam pemvakuman, tingkat ketahanan tabung pyrex, ketidakhati-hatian pada saat proses penggerusan sampel untuk diuji karakterisasi dan pengaruh kontaminasi pada saat uji karakerisasi.

Dilihat dari hasil karaterisasi EDAX diketahui bahwa proses preparasi ini berhasil karena terbentuknya masif dengan unsur $\mathrm{Cd}$, Se dan Te.

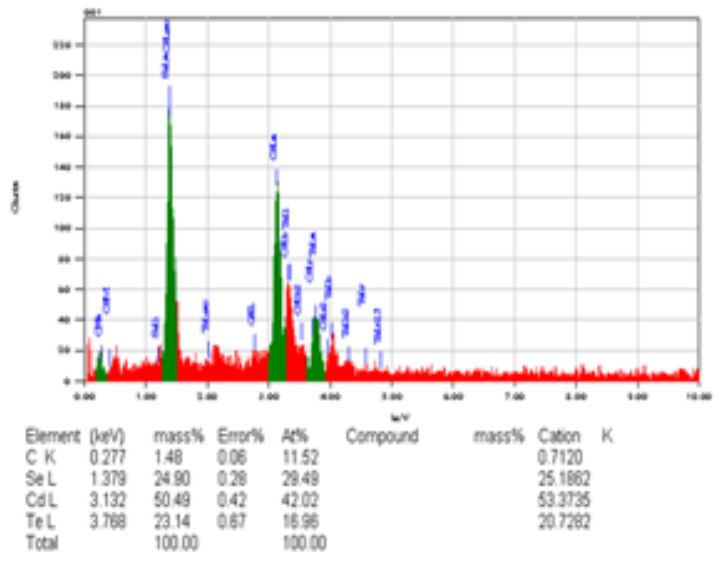

Morfologi Permukaan Masif $\mathrm{Cd}(\mathrm{Se} 0,6 \mathrm{Te} 0,4)$ dengan SEM

SEM digunakan untuk mengetahui struktur morfologi permukaan dari masif. Melalui karakterisasi dengan SEM dihasilkan gambar yang menunjukkan bahwa kristal $C d(\mathrm{Se} 0,6 \mathrm{Te} 0,4)$ homogen, hal ini terlihat dari warna pemukaan kristal hasil preparasi yang seragam dan jika ukuran gambar semakin diperbesar maka semakin tampak butiran kristal yang terkandung dalam masif $\mathrm{Cd}(\mathrm{SeO}, 6 \mathrm{TeO}, 4)$ yang terbentuk.

\section{KESIMPULAN}

Setelah melalui penelitian, analisis data dan karakterisasi dari hasil preparasi bahan $\mathrm{Cd}(\mathrm{Se} 0,6$ Te0,4) dengan metode Bridgman, maka dapat ditarik kesimpulan sebagai berikut:

1. Berdasarkan data hasil karakterisasi XRD, kristal yang terbentuk dari hasil preparasi bahan $\mathrm{Cd}(\mathrm{Se} 0,6 \mathrm{Te} 0,4)$ berupa kristal dengan struktur hexagonal.

2. Parameter kisi pada kristal $C d(\mathrm{Se} 0,6 \mathrm{Te} 0,4)$ hasil preparasi adalah $\mathrm{a}=\mathrm{b}=4,2941 \AA$ dan $\mathrm{c}=$ $6,9975 \AA$ Á, sedangkan dari data JCPDS CdSe adalah $\mathrm{a}=\mathrm{b}=4,2990 \AA \hat{\text { dan }} \mathrm{c}=7,0100 \AA$.

3. Hasil karakterisasi EDAX menunjukan telah terbentuk $\mathrm{Cd}(\mathrm{SeO}, 6 \mathrm{Te} 0,4)$ dengan perbandingan komposisi kimia unsur $\mathrm{Cd}$ :Se:Te adalah 42.02:29.49:16.96 sedang perbandingan mol $\mathrm{Cd}:$ Se:Te adalah 1:0.70:0.40.

4. Hasil karakterisasi SEM menunjukkan bahwa morfologi permukaan kristal $\mathrm{Cd}(\mathrm{SeO}, 6 \mathrm{Te} 0,4)$ homogen, hal ini terlihat dari warna seragam pada permukaan kristal.

\section{UCAPAN TERIMAKASIH}

Terimakasih kepada Dr. Ariswan dan Dr. Heru Kuswanto yang telah membantu pelaksanaan dan penulisan hasil penelitian sehingga menjadi layak untuk dipublikasikan. Juga kepada 
Pascasarjana Pendidikan Fisika Univesitas Ahmad Dahlan yang telah menjadi fasilitator untuk publikasi karya tulis ini.

\section{DAFTAR ACUAN}

[1] Mukti Dwi Nurjannah. 2010. Studi Pengaruh Alur Pemanasan Terhadap Struktur Kristal, Komposis dan Morfologi Bahan Semikonduktor $\mathrm{Cd}(\mathrm{Se} 0,0 \mathrm{Te} 0,5)$ Hasil Preparasi dengan Metode Brigman. Yogyakarta: FMIPA Universitas Negeri Yogyakarta

[2] Beiser A. 1987. Konsep Fisika Modern Edisi Ketiga, Jakarta: Erlangga

[3] Edi Istiyono, 2000. Fisika Zat Padat I. Diktat Kuliah, tidak diterbitkan, Yogyakarta: Universitas Negeri Yogyakarta

[4] Edi Iswanto, 2007. Prinsip Kerja Sel Surya Sambungan p-n, artikel. www.forumsains.com

[5] Nyoman Suwitra. 1989. Pengantar Fisika Zat Padat. Jakarta: DepDikBud

[6] Ariswan, 2007. Semikonduktor. Handout Kuliah, tidak diterbitkan. Yogyakarta: Universitas Negeri Yogyakarta

[7] R. Balasundaranhul, S. Jayakumar, M. D. Kannan, N. Muthukumarasamy, S. Velumani and H. Castaneda. 2005. Characterization of Hot Wall Deposited Cd(Se0.65Te0.35) Thin Film. USA: Journal of New Material for Electromical System

[8] Ariswan, 2005. Kristalografi. Handout Kuliah, tidak diterbitkan. Yogyakarta: Universitas Negeri YogyakartaS. Iwan, S.T. Tan, J.L. Zhao, and X.W. Sun, Growth process of ZnO nanotubes using MOCVD , J. Crystal Growth. 874 (2010), p. 329-333. 